\title{
Seed Quality Attributes under Different Temperature Regimes Experienced by Parent Plants in Wheat (Triticum aestivum $\mathrm{L}$.)
}

\author{
Archana Sanyal* and Monika A. Joshi \\ Division of Seed Science and Technology, IACR-Indian Agricultural Research Institute, \\ New Delhi-110012, India \\ *Corresponding author
}

\section{A B S T R A C T}

\section{Keywords}

Growth temperature, Seed quality, Wheat genotypes

\section{Article Info}

Accepted:

17 November 2018

Available Online:

10 December 2018
The study was conducted to examine the effect of high temperature on seed quality attributes viz., physical, physiological and biochemical in wheat. Twelve diverse genotype's seed obtained from normal and high temperature growing conditions were tested for quality. High parent plant growth temperature during seed development and maturation resulted in poor seed quality. The effect of parent plant growth temperature on seed germination and emergence was inconsistent among wheat genotypes. Seed vigor as indicated by seed density, conductivity of seed leachates, seedling dry weight and production of normal seedlings, were reduced in all wheat genotypes due to higher parent plant growth temperature but heat-sensitive wheat genotypes were affected more than the heat-tolerant genotypes. Further, total hydrogen peroxide activity was increased and total antioxidant capacity decreased in genotypes obtained from high growth temperature.

\section{Introduction}

Seeds are the foundation of agriculture and key component of various cropping system to ensure optimum plant population. Technology has modernized much of farming's day-to-day operations, but without a high-quality seed, yields and crop quality would be decrease greatly. Quality seed increased crop yield by 20 to $25 \%$ with the optimum agronomic practices. The ability of the seed to germinate, emerge into a uniform and vigorous field stand is a direct function of its quality (Grass et al., 1994 and Hasan et al., 2013). There is sufficient evidence that the parental growth environment influenced the quality of the seed produced. Variation in Seed quality, attributed to differences in environmental conditions prevailing during the formation, development, and maturation of the seed while still on the mother plant (Datta et al., 1972; Peacock and Hawkins 1970).

Common wheat (Triticum aestivum L.) belongs to family Poaceae and it is the most important staple food crop in the world and second important crop in India after rice. However, almost $60 \%$ of country's net cultivated area is rain fed and exposed to several abiotic and biotic stresses including heat stress. In India, delay in wheat sowing due to rice-wheat cropping system is one of 
the major factors responsible for reduced seed quality due to the sub-optimal temperature during germination, plant establishment and reproductive growth (Sattar et al., 2010). High temperature following anthesis adversely affects grain development in wheat (Hasan and Ahmed 2005; Tashiro and Wardlaw 1990). High temperature accelerates the initial grain growth rate but shortens the grain growth period (Hasan and Ahmed 2005; Sofield et al., 1977). There is general observation that the viability and the performance of the seed during its early stages of germination may be related to the conditions under which that seed had formed, developed, and matured.

Seed development at high temperature can affect membrane integrity and can cause an increase in membrane leakage of both electrolytes and macromolecules during germination, which subsequently impairs germination and seedling vigor (Hassan et al., 2013)). Grass and Burris (1995a) reported impaired germination and decline in seed vigor in wheat reflected in reduced shoot and root dry weight and higher seed conductivity due to high temperature during seed development and maturation.

Environmental stress induces the accumulation of reactive oxygen species (ROS) in the cells, which can cause severe oxidative damage to the plants, effect seed development. This oxidative stress may lead to membrane damage during seed imbibition and germination results in poor germination and vigor of seedling (Mullineaux and Baker, 2010; Sharma et al., 2012). Although, the effect of heat stress on wheat yield and yield components is well documented, however, seed quality is often ignored in these studies. Therefore, the objective of the present study was to examine the effect of high temperature on seed quality attributes viz., physical, physiological and biochemical in wheat.

\section{Materials and Methods}

Experiments were conducted at the research farm of the Division of Seed Science and Technology (DSST), IARI, New Delhi, during rabi (November-April) 2015-16 and 2016-17. Twelve diverse germplasm of wheat were sown in two different date of sowing to achieve two contrast temperature condition. Twelve wheat genotypes namely CMS 2019, 2041, 2046, 3083, B 2019, 2041, 2046, 3083, T 2003 R, R 902, R 958 and R 965 were sown in the field on first forth night of November and second forth night of December to expose the wheat genotypes to normal growing temperatures and natural high temperature stress during reproductive development. The seeds of twelve wheat genotypes collected from both normal growing temperatures and natural high temperature stress, dried to $12 \%$ moisture content and then kept in airtight plastic jars. The seeds were stored at $10{ }^{\circ} \mathrm{C}$, $45 \% \mathrm{RH}$ and six months after storage, tested for seed quality as follows below.

Seed density determination was determined using the toluene displacement method (Mohsenin, 1986). True density had estimated as the ratio of 100 seed mass to the volume of displaced toluene. Electrical conductivity test of seed leachates was measured after $24 \mathrm{~h}$ and expressed as $\mu \mathrm{S} \mathrm{cm} \mathrm{cm}^{-1}$ of seed after deducting the initial reading (ISAT 2017). Emergence germination and vigor was determined according to ISTA 2017 in replication.

Hydrogen peroxide activity was estimated by using Titanium-reagent (Mukherjee et al., 1983), a source of ROS generation. Hydrogen peroxide activity expressed as $m g \mathrm{H}_{2} \mathrm{O}_{2}$ g- ${ }^{1}$ fresh weight. The free radical scavenging capacity of the extracts was determined using DPPH (Prieto et al., 1999) as total antioxidant potential. 


\section{Data analysis}

The data was analyzed following two factors (wheat genotypes and parent plant growth temperature) analysis in completely randomized design (CRD) using OPSTAT online statistical tool.

\section{Results and Discussions}

\section{Seed density}

The temperature at which the seeds had developed and the wheat genotypes interacted significantly to influence the seed density. Seed density of different wheat genotypes obtained from both normal and post-anthesis heat stress conditions was determined and the results shown in Table 1 . The density of seeds obtained from normal growing conditions ranged from 1.13-1.59 $\mathrm{g} / \mathrm{cc}^{-1}$ in twelve genotypes including under normal sown condition. Due to higher mother plant temperature after anthesis, the density of seeds reduced significantly in all wheat genotypes with different percent. Maximum reduction showed by 2041 B of $34.22 \%$ followed by CMS 2041 (18.39\%) while, minimum in CMS $3083(1.64 \%)$. Due to higher mother plant temperature after anthesis, the density of seed was reduced significantly in all wheat genotypes. Lu et al., (1993) and Hasan et al., (2013) also found reduced grain density in maize and wheat seed respectively due to high temperature during seed development.

\section{Conductivity of seed leachates}

The conductivity of leachates $\left(\mu \mathrm{S} \mathrm{cm} \mathrm{cm}^{-1} \mathrm{~g}^{-1}\right.$ seed) of seeds obtained from all treatment combinations increased with time at the start of the imbibition but seeds produced at high temperature stress released more electrolytes than those produced at normal conditions throughout the period of measurement (Fig. 1). At $24 \mathrm{~h}$ after the start of imbibition, the seeds harvested from late sown parental lines, released more leachates $(30.85 \%)$ in comparison to timely sown parental lines irrespective of CMS, Maintainer and Restorer lines. CMS 2046, among CMS line from high temperature, produced $31.47 \%$ more electrolytes as compare to normal sown condition. While CMS 2019 produced 24.69 $\%$ more electrolytes in comparison to seed from normal sown condition. However, 3083 B genotype produced only $30.96 \%$ higher than its normal sown' seed. Seeds obtained from late sown condition in Restorer lines, produced lowest amount of leachates at $24 \mathrm{~h}$, ranged from 20.87 to $33.40 \%$ more leachates in compare to seeds from normal sown condition. R 965 seed produced $20.87 \%$ more leachates while, T2003R seed produced $33.40 \%$ more leachates as compare to their seeds obtained from normal sown condition. Grass and Buris (1995a) also found similar results in wheat. Khan and Laude (1969) in their study on barley showed that exposing plants at seed maturity to very high temperature resulted in thinner seed coats. The increase in the conductivity of seed leachates in response to heat stress indicates a difference in the potential vigor of seed obtained from normal and post-anthesis heat stress conditions.

\section{Seedling emergence}

Seedling emergence (percentage) was influenced significantly by the combined effect of genotypes and parent plant growth temperature after anthesis (Table 1). Among the seeds of different genotypes obtained from normal parent plant growth temperature, showed $100 \%$ seedling emergence, except for CMS 2046 (96\%), 2041 B (96\%) and R 958 $(96 \%)$. Emergence \% significantly decreased in genotypes obtained from late sown heat stress condition, average reduction $8.1 \%$ observed in seeds obtained from late sown parental lines. Maximum reduction was 
recorded in R 902 (16\%) precedes by $\mathrm{T} 2003$ R (12\%) and CMS 2041 (12\%), while minimum in CMS 3083 and 2019 B with 4.0 $\%$ only

\section{Germination and seedling vigor}

Standard germination tests were conducted on seed lots stored 6 months under $10{ }^{\circ} \mathrm{C}, 45 \%$ RH. Different wheat parent lines and their growing conditions interacted significantly to influence the final germination (percentage) of the subsequent seed (Table 2). The germination percentage (production of normal seedlings) was ranged from $92-100 \%$ in seeds obtained from parental lines, sown under normal temperature condition, while it ranged $80-96 \%$ in seeds harvested from late sown parental lines. The reduction percent also varied significantly among the genotypes, average reduction \% was $10.3 \%$ (Fig. 2). Reduced germination could be attributed to seed damage by high temperature conditions during seed development and maturation (Grass and Burris 1995a). Grass and Burris (1995a) and Moss and Mullett (1982) obtained significant interaction between genotypes and the temperature conditions experienced by the parent plants during seed development and maturation for the wheat seed germination. The same interaction was also significant in the present study.

Seed Vigor Index is expressed in terms of VI and VII significantly influence by parental growth condition (Fig. 3) especially under stress condition. VI is factor of seedling length and germination percent, while VII is factor of seedling dry weight and germination percent. Average reduction in VI and VII observed was 31.6 and $25.3 \%$ respectively in seeds of late sown parental lines. Further, maximum reduction in VI, showed by CMS lines (average $34.1 \%$ ) proceeds by Maintainer lines (30.6\%) and Restorer lines (30.2\%). Similarly, highest reduction in VII was observed in
T2003 R (35.0\%) and minimum in $2041 \mathrm{~B}$ $(10.2 \%)$ from the average reduction of $25.3 \%$. Sechnyak et al., (1985) and Grass and Burris (1995a) reported decreased seedling weight with an increase in parent plant temperature in wheat while Keigley and Mullen(1986) and Egli et al., (2005) in soybean, Fussel and Pearson (1980) in pearl millet grain and Steiner and Opoku-Boateng (1991) in mature lettuce seed. These studies mostly related to decline in vigor with seed size. However, Siddique and Goodwin (1980) showed that alone seed size did not contribute the negative effect of high temperature on parent plants. Further, Moss and Mullett (1982) suggested that the rate of drying and rapid desiccation affect the maturation of seeds at high temperature might affect the maturation process and attainment of high seed vigor. The results of the present study support that hypothesis, because the seeds developed under high temperature conditions matured earlier and dried faster than the seeds produced at normal growing conditions.

\section{Hydrogen peroxide activity}

Hydrogen peroxide production is result of lipid peroxidation of cell membrane due to heat stress experienced by plant system, $\mathrm{H}_{2} \mathrm{O}_{2}$ is non -radical ROS cause severe damages to plant metabolism.

In present study, $\mathrm{H}_{2} \mathrm{O}_{2}$ accumulation increased in seeds of late sown parental lines under high temperature stress. It ranged from 1.39 to 2.28 $\mathrm{mg} / \mathrm{g} \mathrm{FW}$ of seed obtained from normal sown condition, whereas, seeds obtained from late sown parental lines, $\mathrm{H}_{2} \mathrm{O}_{2}$ accumulation ranged from 1.53 to $2.98 \mathrm{mg} / \mathrm{g} \mathrm{FW}$ (Table 3). Highest accumulation was observed in 2019 $\mathrm{B}$, a Maintainer line of $2.98 \mathrm{mg} / \mathrm{g}$ FW with $30.9 \%$ in comparison to normal sown condition, precedes by $2041 \mathrm{~B}(2.79 \mathrm{mg} / \mathrm{g}$ FW) and $2046 \mathrm{~B}(2.33 \mathrm{mg} / \mathrm{g} \mathrm{FW})$ and $3083 \mathrm{~B}$ $(2.28 \mathrm{mg} / \mathrm{g} \mathrm{FW})$. The increased percent of 
accumulation was $22.6 \%, 16.1 \%$ and $17.9 \%$ in $2041 \mathrm{~B}, 2046 \mathrm{~B}$ and 3083B individually (Fig. 3).

Among CMS lines, highest percentage of accumulation was observed in CMS 2019 (21.9\%) with value of $2.73 \mathrm{mg} / \mathrm{g} \mathrm{FW}$, which was also highest in terms of quantity. Whereas lowest percentage of accumulation was observed in CMS 2041 (5.6\%) with 1.53 $\mathrm{mg} / \mathrm{g} \mathrm{FW}$, compare to seeds obtained from late sown parental lines. Restorer lines, showed the same trend of $\mathrm{H}_{2} \mathrm{O}_{2}$ accumulation, average value of $\mathrm{H}_{2} \mathrm{O}_{2}$ in seeds obtained from normal sown Restorer lines was $2.14 \mathrm{mg} / \mathrm{g}$ FW, while the seeds, which was, harvested from late sown Restorer lines it was 2.56 $\mathrm{mg} / \mathrm{g}$ FW. Caverzan et al., (2016) also reviewed that any stress condition including heat stress is responsible for excessive ROS generation in cell, affect cell membrane activity.

\section{Total Antioxidant Capacity (TAC)}

DPPH scavenging capacity test used as a significant tool to identify the primary antioxidants, which can donate the hydrogen to scavenge free radicals. DPPH antioxidant assay based on the ability of 1,1-diphenyl-2picryl-hydrazyl (DPPH), a stable free radical, to decolorize in the presence of antioxidants. The DPPH radical contains an odd electron, which is responsible for the absorbance at 517 $\mathrm{nm}$ and for a visible deep purple color. When DPPH accepts an electron donated by an antioxidant compound, the DPPH is decolorized, which can be quantitatively measured from the changes in absorbance.

Table.1 Effect of genotypes and parental growth temperature on physical seed quality

\begin{tabular}{|c|c|c|c|c|c|c|c|}
\hline \multirow[t]{2}{*}{ SL. No. } & \multirow[t]{2}{*}{ Genotypes } & \multicolumn{3}{|c|}{ Seed Density (g/g) } & \multicolumn{3}{|c|}{ Emergence \% } \\
\hline & & NS & $\mathbf{L S}$ & $\mathbf{R P}(\%)$ & NS & $\mathbf{L S}$ & $\mathbf{R P}(\%)$ \\
\hline 1 & CMS 2019 & 1.49 & 1.24 & 16.8 & 100.0 & 92.0 & 8.0 \\
\hline 2 & CMS 2041 & 1.33 & 1.08 & 18.4 & 100.0 & 88.0 & 12.0 \\
\hline 3 & CMS 2046 & 1.36 & 1.25 & 8.1 & 96.0 & 92.0 & 4.2 \\
\hline 4 & CMS 3083 & 1.16 & 1.14 & 1.6 & 100.0 & 96.0 & 4.0 \\
\hline 5 & 2019 B & 1.59 & 1.44 & 9.0 & 100.0 & 96.0 & 4.0 \\
\hline 6 & $2041 \mathrm{~B}$ & 1.28 & 0.85 & 34.2 & 96.0 & 92.0 & 4.2 \\
\hline 7 & 2046 B & 1.21 & 1.10 & 8.9 & 100.0 & 92.0 & 8.0 \\
\hline 8 & $3083 \mathrm{~B}$ & 1.13 & 1.08 & 4.9 & 100.0 & 92.0 & 8.0 \\
\hline 9 & T2003 R & 1.23 & 1.00 & 18.5 & 100.0 & 88.0 & 12.0 \\
\hline 10 & R 902 & 1.28 & 1.09 & 14.4 & 100.0 & 84.0 & 16.0 \\
\hline 11 & R 958 & 1.45 & 1.27 & 12.0 & 96.0 & 88.0 & 8.3 \\
\hline \multirow[t]{3}{*}{12} & R965 & 1.56 & 1.22 & 22.2 & 100.0 & 92.0 & 8.0 \\
\hline & Mean & 1.34 & 1.15 & 14.1 & 99.0 & 96.0 & 8.1 \\
\hline & & & SD & \multicolumn{4}{|c|}{ Emergence \% } \\
\hline \multicolumn{3}{|c|}{ Genotype } & N/A & & \multicolumn{2}{|r|}{ N/A } & \\
\hline \multicolumn{3}{|c|}{ Temperature } & 0.145 & & \multicolumn{2}{|r|}{2.187} & \\
\hline \multicolumn{3}{|c|}{ Genotype X Temperature } & N/A & & \multicolumn{2}{|r|}{ N/A } & \\
\hline
\end{tabular}


Table.2 Effect of genotypes and parental growth temperature on seed vigor

\begin{tabular}{|c|c|c|c|c|c|c|c|c|c|c|c|c|c|}
\hline $\begin{array}{l}\text { SL. } \\
\text { No. }\end{array}$ & Genotypes & \multicolumn{3}{|c|}{ Germination (\%) } & \multicolumn{3}{|c|}{ Seedling length $(\mathrm{cm})$} & \multicolumn{3}{|c|}{ Seedling Dry weight (g) } & \multicolumn{3}{|c|}{ Vigour Index II } \\
\hline 2 & CMS 2041 & 100.0 & 80.0 & 20.0 & 37.17 & 27.05 & 27.2 & 0.81 & 0.66 & 18.2 & 80.94 & 52.96 & 34.6 \\
\hline 3 & CMS 2046 & 96.0 & 80.0 & 16.7 & 33.47 & 26.65 & 20.4 & 0.79 & 0.71 & 10.9 & 76.11 & 56.49 & 25.8 \\
\hline 5 & $2019 \mathrm{~B}$ & 96.0 & 88.0 & 8.3 & 32.44 & 24.15 & 25.5 & 0.85 & 0.67 & 21.0 & 81.30 & 58.88 & 27.6 \\
\hline 6 & $2041 \mathrm{~B}$ & 100.0 & 96.0 & 4.0 & 34.12 & 26.20 & 23.2 & 0.88 & 0.82 & 6.4 & 87.61 & 78.69 & 10.2 \\
\hline 7 & 2046 B & 100.0 & 84.0 & 16.0 & 33.96 & 26.15 & 23.0 & 0.88 & 0.68 & 22.5 & 87.52 & 56.99 & 34.9 \\
\hline 8 & $3083 \mathrm{~B}$ & 100.0 & 88.0 & 12.0 & 33.58 & 27.10 & 19.3 & 0.87 & 0.68 & 21.4 & 86.67 & 59.91 & 30.9 \\
\hline 11 & R 958 & 100.0 & 88.0 & 12.0 & 33.48 & 26.70 & 20.2 & 0.87 & 0.78 & 10.4 & 87.03 & 68.64 & 21.1 \\
\hline \multirow[t]{2}{*}{12} & R965 & 96.0 & 86.0 & 10.4 & 33.70 & 26.60 & 21.1 & 0.81 & 0.79 & 2.4 & 77.78 & 68.02 & 12.6 \\
\hline & Mean & 98.2 & 87.8 & 10.6 & 34.22 & 26.15 & 23.5 & 0.86 & 0.71 & 16.4 & 84.13 & 62.84 & 25.3 \\
\hline \multicolumn{3}{|c|}{ Factor } & G\% & SL & \multicolumn{2}{|c|}{ SDW } & VII & & & & & & \\
\hline \multicolumn{3}{|c|}{ Genotype } & 0.993 & 0.328 & \multicolumn{2}{|c|}{0.028} & 5.628 & & & & & & \\
\hline \multicolumn{3}{|c|}{ Temperature } & 0.406 & 0.134 & \multicolumn{2}{|c|}{0.012} & 2.297 & & & & & & \\
\hline \multicolumn{3}{|c|}{ Genotype X Temperature } & 1.405 & 0.464 & \multicolumn{2}{|c|}{0.04} & 7.959 & & & & & & \\
\hline
\end{tabular}


Table.3 Effect of genotypes and parental growth temperature on biochemical parameter of seed quality

\begin{tabular}{|c|c|c|c|c|c|c|c|c|}
\hline \multirow{2}{*}{$\begin{array}{l}\text { SL. } \\
\text { No. }\end{array}$} & \multirow[t]{2}{*}{ Genotype } & \multicolumn{4}{|c|}{ Total $\mathrm{H}_{2} \mathrm{O}_{2}$ activity $(\mathrm{mg} / \mathrm{g})$} & \multicolumn{3}{|c|}{ Total Antioxidant Activity (mg/g) } \\
\hline & & \multicolumn{2}{|l|}{ NS } & LS & $\mathbf{R P}(\%)$ & NS & LS & $\mathbf{R P}(\%)$ \\
\hline 1 & CMS 2019 & \multicolumn{2}{|l|}{2.24} & 2.73 & 21.9 & 3.87 & 4.75 & 18.6 \\
\hline 2 & CMS 2041 & \multicolumn{2}{|l|}{1.45} & 1.53 & 5.6 & 4.12 & 4.98 & 17.4 \\
\hline 3 & CMS 2046 & \multicolumn{2}{|l|}{1.39} & 1.54 & 10.8 & 4.13 & 5.34 & 22.6 \\
\hline 4 & CMS 3083 & \multicolumn{2}{|l|}{1.68} & 1.87 & 11.7 & 4.17 & 5.41 & 22.9 \\
\hline 5 & 2019 B & \multicolumn{2}{|l|}{2.28} & 2.98 & 30.9 & 4.06 & 4.84 & 16.1 \\
\hline 6 & $2041 \mathrm{~B}$ & \multicolumn{2}{|l|}{2.28} & 2.79 & 22.6 & 4.28 & 5.05 & 15.4 \\
\hline 7 & $2046 \mathrm{~B}$ & \multicolumn{2}{|l|}{2.00} & 2.33 & 16.1 & 4.12 & 5.37 & 23.4 \\
\hline 8 & $3083 \mathrm{~B}$ & \multicolumn{2}{|l|}{1.93} & 2.28 & 17.9 & 4.24 & 5.46 & 22.4 \\
\hline 9 & T2003 R & \multicolumn{2}{|l|}{1.79} & 1.82 & 1.3 & 3.99 & 4.77 & 16.3 \\
\hline 10 & R 902 & \multicolumn{2}{|l|}{2.26} & 2.94 & 30.2 & 4.17 & 5.23 & 20.3 \\
\hline 11 & R 958 & \multicolumn{2}{|l|}{2.28} & 2.72 & 19.5 & 4.10 & 4.84 & 15.4 \\
\hline \multirow[t]{2}{*}{12} & R965 & \multicolumn{2}{|l|}{2.22} & 2.78 & 25.2 & 4.24 & 5.39 & 21.4 \\
\hline & Mean & \multicolumn{2}{|l|}{1.98} & 2.36 & 17.8 & 4.12 & 5.12 & 19.4 \\
\hline \multicolumn{2}{|c|}{ Factor } & HPC & \multicolumn{3}{|l|}{ TAA } & & & \\
\hline \multicolumn{2}{|c|}{ Genotype } & 0.043 & \multicolumn{2}{|l|}{0.038} & & & & \\
\hline \multicolumn{2}{|c|}{ Temperature } & 0.017 & \multicolumn{2}{|l|}{0.016} & & & & \\
\hline \multicolumn{2}{|c|}{ Genotype X Temperature } & 0.06 & \multicolumn{2}{|l|}{0.054} & & & & \\
\hline
\end{tabular}


Fig.1 Effect of sowing time on Physical Seed quality (a) Mean of EC (b): Mean EC of CMS lines during 24 h; (c): Mean EC of Maintainer lines during 24 h; (d): Mean EC of Restorer lines during $24 \mathrm{~h}$; Vertical bars indicate $\pm \mathrm{SD}$ of mean

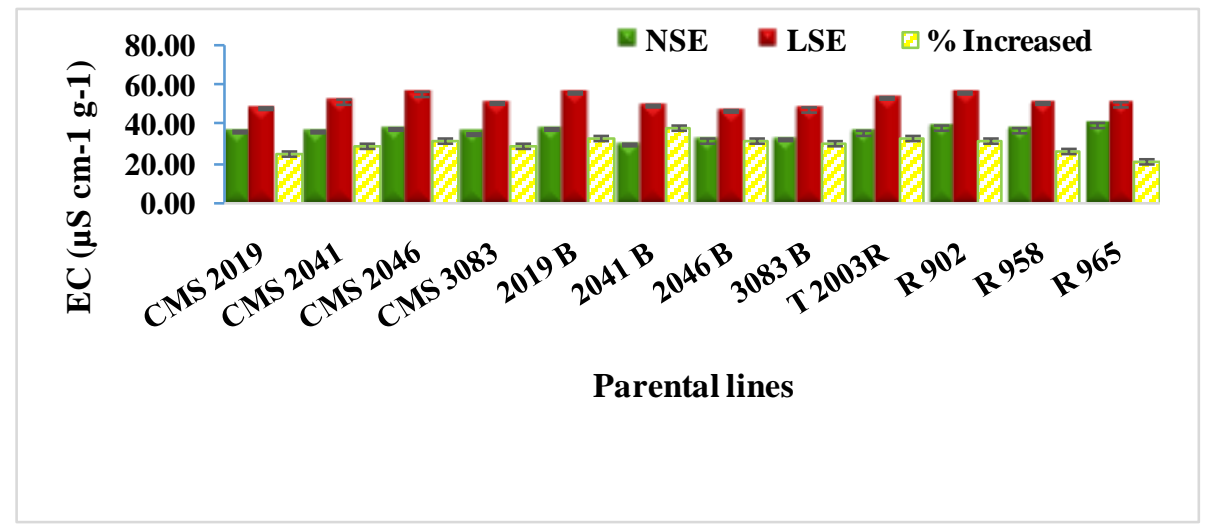

(a)

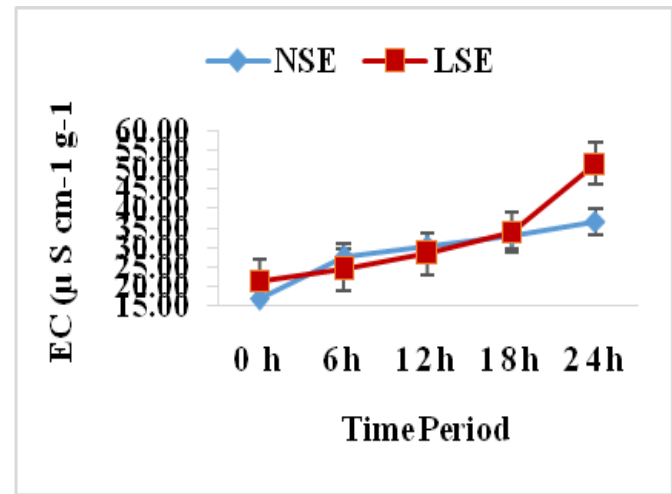

(b)

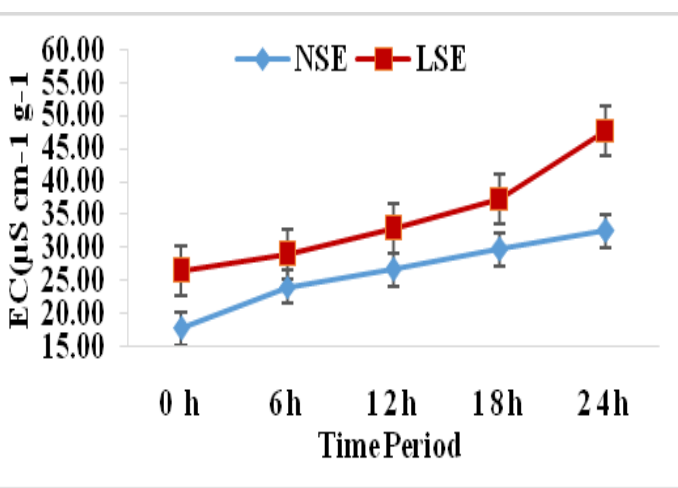

(c)

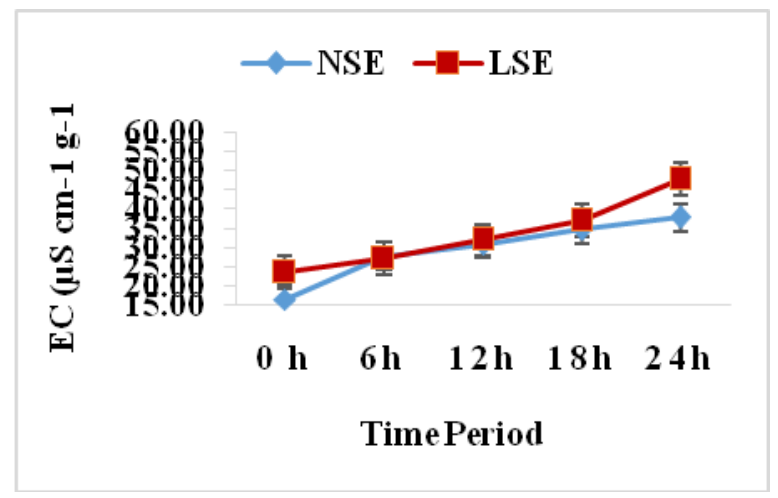

(d) 
Fig.2 Effect of temperature on seed vigour; (a): Emergence percentage, (b): Seedling length, (c): seedling dry weight

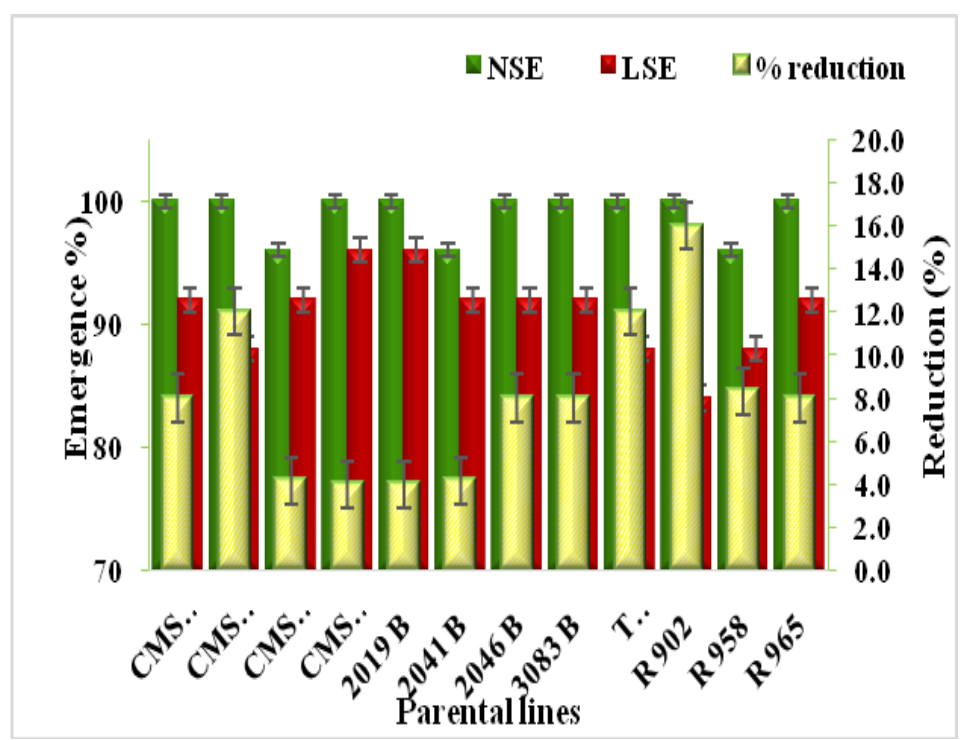

(a)

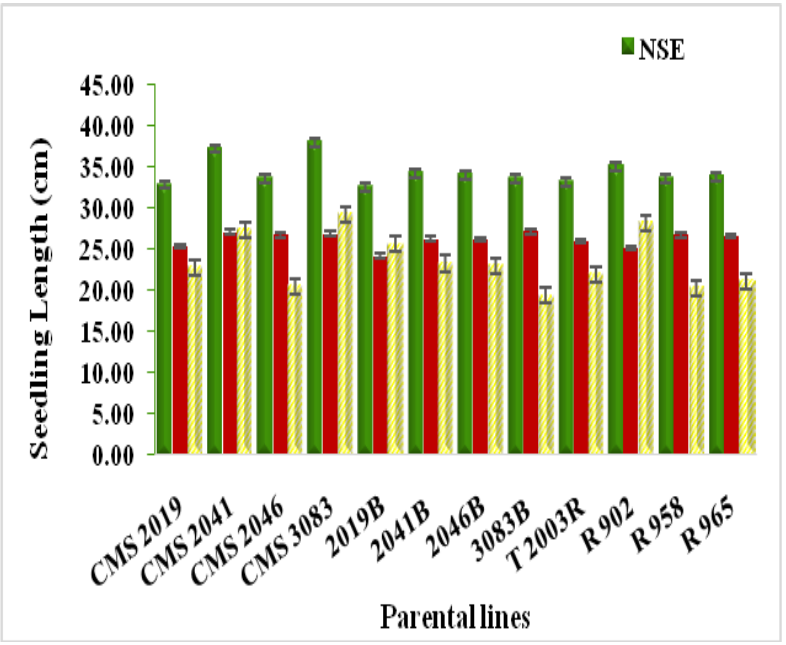

(b)

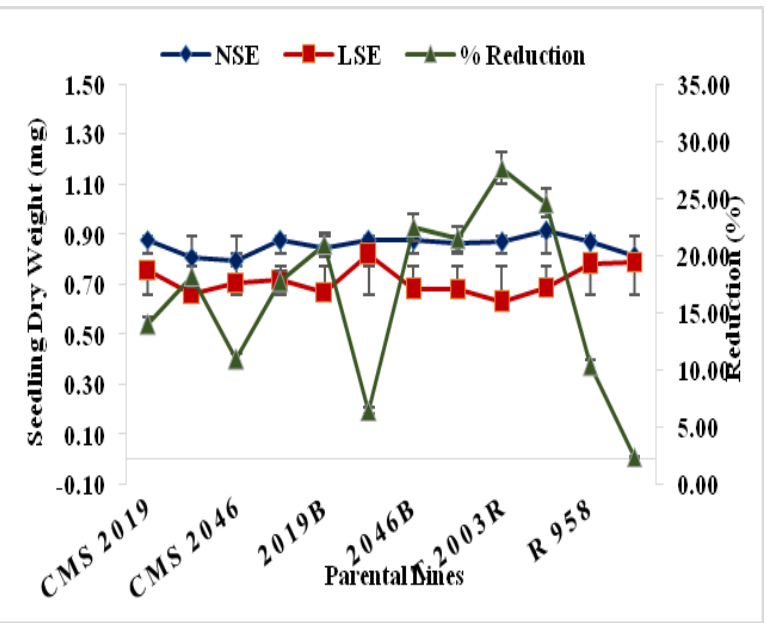

(C) 
Fig.3 Effect of sowing time on Antioxidant Potential (a) Hydrogen Peroxide Activity (HPA). (b): Total antioxidant capacity (TAC). Vertical bars indicate \pm SD of mean

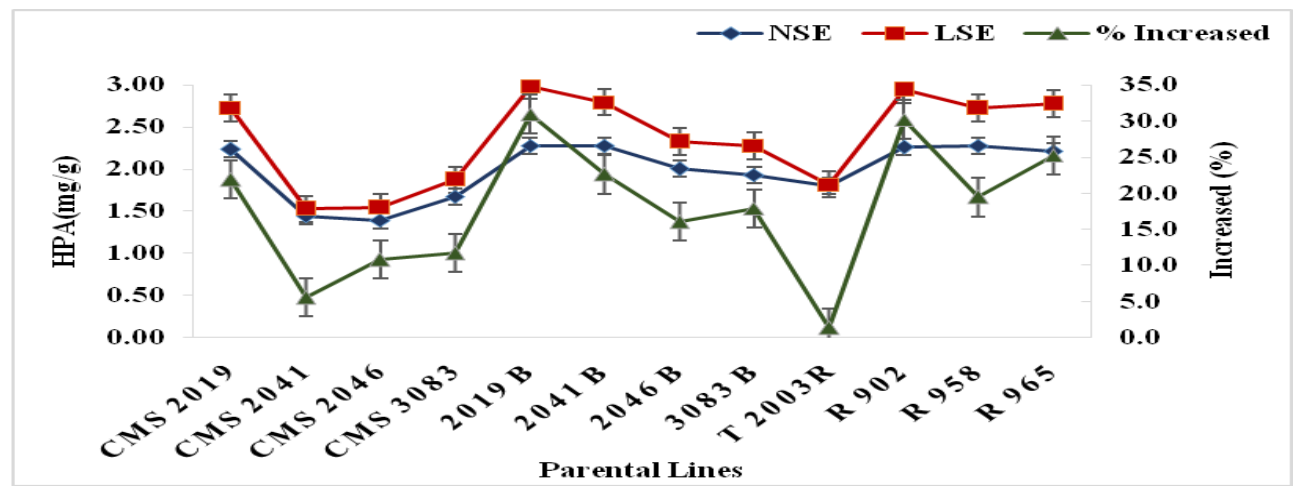

(a)

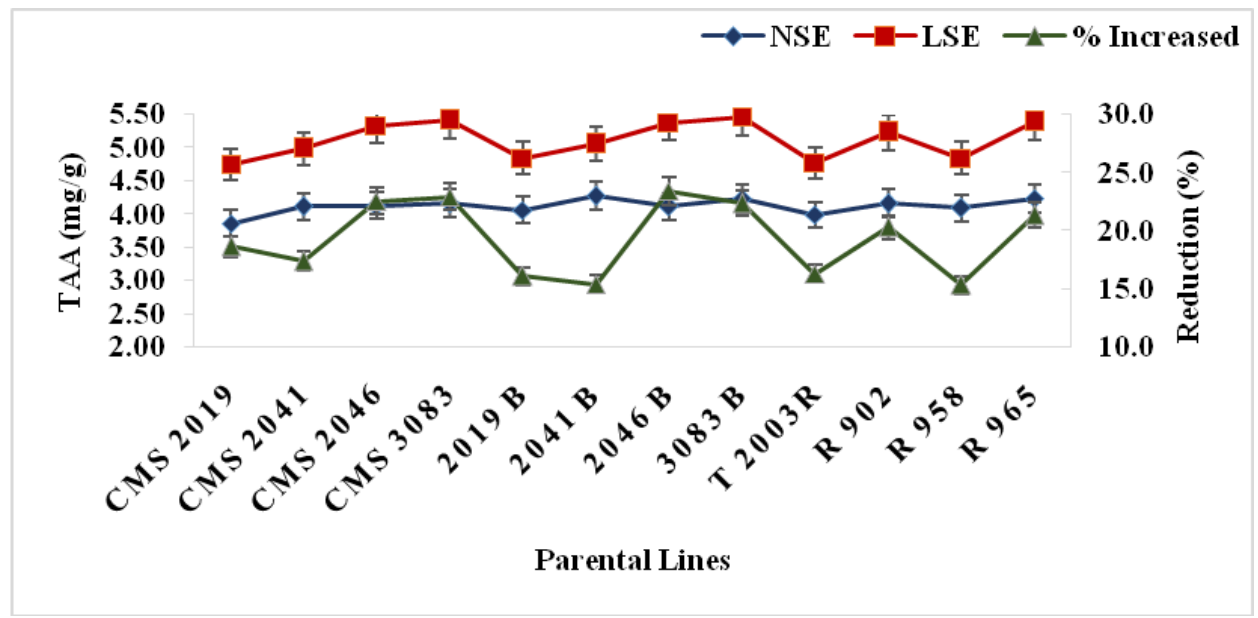

(b)

A significant difference was observed for Antioxidant potential observed, irrespective of genotypes. Antioxidant potential/ activity was ranged from $3.87-4.28 \mathrm{mg} / \mathrm{gof}$ fresh weight of seed obtained from late sown parental lines, while it ranged from $4.7-5.7$ $\mathrm{mg} / \mathrm{g}$ of fresh weight of seed obtained from normal sown parental lines (Table 3 ).

Among the CMS lines, scavenging activity significantly reduced in CMS 3083 (22.9\%), while in CMS 2046, CMS 2041 and CMS 2019 it decreased by $22.6 \%, 17.4 \%$ and $18.6 \%$ individually. 2046 B, Maintainer line showed maximum reduction in activity (23.4\%) among Maintainer lines seeds, harvested from late sown parental lines.
While, minimum reduction was observed in 2041 B (15.4\%). Restorer lines showed lowest average value (18.4\%) of decreased activity in seeds of late sown parental lines compare to other CMS (20.4\%) and Maintainer line's $(19.3 \%)$ genotypes. Although, R 965 (21.4\%) seeds on fresh weight basis showed highest percent of reduction, however other genotypes also showed significant decreased scavenging activity. In R 902 activity was decreased by 20.3\%, while, in R 958 and T2003 R it reduced by $15.4 \%$ and $16.3 \%$ individually (Fig. 3). Dasgupta et al., (2007) and Venkatachalam et al., (2014) also found decreased TAC under stress conditions results in low vigor of seed. 
High temperature during seed development, observed by parent could results in low quality of seed. Seed deterioration starts, when seed is still on mother plants and environment during that time affect its viability and vigor. High temperature stress in late sown condition, duration of life cycle stages of our tested wheat parental lines reduced. Normal sown condition (i.e. optimum sowing on November) resulted in better performance of all genotypes than late sowing. From overall performance, CMS 3083, CMS 2046, R 958 and R 965 were considered to be the best performing parental lines under heat stress while CMS 2019, CMS 2041, T 2003R were found to be sensitive to heat for most of the studied parameters. Seed vigor as indicated by seed density, seed conductivity, seedling dry weight, production of normal seedling, seed reserve utilization efficiency, and seedling emergence was affected more in heat-sensitive wheat genotypes than the heat-tolerant genotypes due to higher parent plant growth temperature. Timely sowing is best solution to harvest quality seed with high vigor and viability. In present, climate change is major problem for agriculture; with this situation, growth temperature is increasing rationally, may lead to deteriorated seed. Seed priming could play vital role to mitigate high temperature stress condition.

\section{References}

Caverzan A., Casassola, A. and Brammer, S. P. (2016). Antioxidant responses of wheat plants under stress. Genetics and Molecular Biology, 39 (1): 1-6

Dasgupta N. and De, B. (2007). Antioxidant activity of some leafy vegetables of India: A comparative study. Food Chemistry 101 (2): 471-474.

Datta S.C., Gutterman Y and Evenari M. (1972). The influence of the origin of the mother plant on yield and germination of their caryopsis in Aegilops ovata. Planta 105: 155-164

Egli D.B., Tekrony, D.M., Heitholt J.J. and Rupe J. (2005). Air temperature during seed filling and soybean seed germination and vigor. Crop Sci. 45: 1329-1335

Fussel L.K., Pearson C.J. (1980). Effects of grain development and thermal history on grain maturation and seed vigor of Pennesetum americanum. J. Exp. Bot. 121: 635-643

Grass L. and Burris J.S. (1995a). Effect of heat stress during seed development and maturation on wheat seed quality. I. Seed germination and seedling vigor. Can. J. Plant Sci. 75:821-829.

Handbook of seed testing. (2017). International seed Testing Association (Geneva)

Hasan M. A., Ahmed J.A., Hossain T., Khaleque M.A. and Haque, M.M. (2013). Evaluation of the Physiological Quality of Wheat Seed as Influenced by High Parent Plant Growth Temperature. J. Crop Sci. Biotech. 2013. 16 (1): 69-74.

Hasan M.A. and Ahmed J.U. (2005). Kernel growth physiology of wheat under late planting heatstress. J. of the Natl. Sci. Found. Sri Lanka. 33 (3): 193204.

Keigley P.J. and Mullen R.E. (1986). Changes in soybean quality from high temperature during seed filling and maturation. Crop Sci. 26: 1212-1216

Khan R.A. and Laude H.M. (1969). Influence of heat stress during seed maturation on germinability of barley seed at harvest. Crop Sci. 9: 55-58

Lu T.J., Jane J.L., Keeling P.L. and Singletary G.W. (1993). Effect of temperature on the fine structure on maize starch. Cer. Foods. 38: 617.

Mohsenin N. N. (1986). Physical properties of plant and animal materials. New 
York: Gordon and Breach.

Moss G.I. and Mullett J.H. (1982). Potassium release and seed vigor in germinating bean (Phaseolus vulgaris L.) seed as influenced by temperature over the previous generations. J. Exp. Bot. 33: 1147-1160.

Mukherjee S.P. and Choudhuri M.A. (1983). Implications of water stress induced changes in the levels of endogenous ascorbic acid and hydrogen peroxide in Vigna seedlings. Physiol Plant 58:166170.

Mullineaux P.M. and Baker N.R. (2010) Oxidative stress: antagonistic signaling for acclimation or cell death? Plant Physiol 154:521-525.

Peacock H.A., Hawkins B.S. (1970). Effect of seed source on seedling vigor, yield, and lint characters of upland cotton. Crop Sci. 10:667-760

Prieto P., Pineda M. and Aguilar M. (1999). Spectrophotometric quantitation of antioxidant capacity through the formation of a phosphormolybdenum complex: specific application to the determination of vitamin E1. Analytical Biochemistry 269: 337-341.

Sattar A., Cheema M.A., Farooq M., Wahid, M.A., Wahid A. and Babar B.H. (2010). Evaluating the performance of wheat varieties under late sown conditions. International J. of Agri and Bio.12: 561-565.
Sechnyak L.K, Kindruk N.A. and Slyusarenko O.K. (1985). New experimental approach to problem of seed ecology. In: Bulletin Problems of Crop Breeding and Genetics. Sofia, pp 254-269

Sharma P., Jha A.B., Dubey R.S. and Pessarakli M. (2012) Reactive oxygen species, oxidative damage, and antioxidative defense mechanism in plants under stressful conditions. $J$ Bot: e217037.

Siddique A.M.D. and Goodwin P.B. (1980). Seed vigor in bean as influenced by temperature and water regime during development and maturation. J. Exp. Bot. 120: 313-323

Steiner J.J. and Opoku-Boateng K. (1991). Natural season-long and diurnal temperature effects on lettuce seed production and quality. J. Amer. Soc. Hort. Sci. 116: 396-400

Tashiro T. and Wardlaw F. (1990). Effect of high temperature at different stage of ripening on grain set, grain weight and grain dimension in the semidwarf wheat 'Bank'. Ann. Bot. 65: 51-61.

Venkatachalam K., Rangasamy R. and Krishnan. (2014). Total antioxidant activity and radical scavenging capacity of selected fruits and vegetables from South India. International Food Research Journal 21(3): 1039-1043.

\section{How to cite this article:}

Archana Sanyal and Monika A. Joshi 2018. Seed Quality Attributes under Different Temperature Regimes Experienced by Parent Plants in Wheat (Triticum aestivum L.) Int.J.Curr.Microbiol.App.Sci. 7(12): 2426-2437. doi: https://doi.org/10.20546/ijcmas.2018.712.276 